Citation:

Ribeiro, N., Gupta, M., Gomes, D. and Alexandre, N. (2021), "Impact of psychological capital (PsyCap) on affective commitment: mediating role of affective well-being", International Journal of Organizational Analysis, Vol. ahead-ofprint No. ahead-of-print. https://doi.org/10.1108/lJOA-04-2020-2122

\title{
Impact of Psychological Capital (PsyCap) on Affective Commitment: Mediating Role of
}

\section{Affective Well-being}

\begin{abstract}
Purpose - The purpose of the study is to examine the mediating role of Affective Well-Being (AWB) in the relationship between Psychological Capital (PsyCap) and Affective Commitment.

Methodology - The sample included 226 employees from diverse Portuguese organizations. Based on a survey, respondents reported their perceptions of own PsyCap, AWB and affective commitment to their organization.
\end{abstract}

Findings - Results from Structural Equation Modeling (SEM) suggested presence of mediation by AWB in the relationship between PsyCap and Affective Commitment.

Practical implications - Managers are encouraged to gain from this finding by emphasizing more on the emotional health of individuals to increase their attachment with the company.

Originality/value - Though there are several studies indicating the positive consequences of PsyCap on employees, studies on how PsyCap affects Affective Commitment through AWB is scarce. These results advance the broaden-and-build theory by suggesting that the relationship between PsyCap and affective commitment is much more complex.

Keywords: Psychological Capital, affective commitment, affective well-being, Portugal. 


\section{Impact of PsyCap on Affective Commitment: Mediating Role of Affective Well-being}

\section{Introduction}

Scholars and practitioners have recognized the importance of positive employee attitude on several positive outcomes (Reynolds and Lewis, 2018) including, well-being, commitment toward the organization, and work performance (Avey et al., 2010; Çetin and Basim, 2011; Culbertson et al., 2010; Shahnawaz and Jafri, 2009; Simons and Buitendach, 2013). Psychological capital (PsyCap) captures and explains this positive attitude. It has been argued that individuals high in PsyCap are psychologically capable and are hopeful, efficacious, resilient, and optimistic (Luthans and Youssef, 2004; Ngoma and Dithan Ntale, 2016; Xu et al., 2017).

Although extant literature suggests that PsyCap does have a positive impact on employee attitudes such as their affective commitment (Akhter et al., 2012; Rego et al., 2012), research on how this relationship occurs is scarce. This study will fill this void by arguing and examining that the PsyCap and affective commitment relationship is in fact complex and worthy of dedicated analysis. Indeed, scholars in the past have suggest that affective well-being is the extent to which individuals have the positive versus negative experiences over a specific period of time (Diener et al., 1985) could have a pivotal role in explaining the relationship between PsyCap and affective commitment (McMurray et al., 2010).

This study covers employees working in the diverse industries in Portugal. The last financial crisis faced by the Portuguese employees have generated a lot of sadness and have created widespread outlook and may have caused a decline in positive employee attitudes and behaviors. Many workers have experienced reduced wages and benefits during that period. In adverse context, 
only an employee who is positive, hopeful, confident, resilient, and optimistic can remain affectively committed. PsyCap is one of the personal resources that keep employees emotionally committed to the organization (Luthans et al., 2006).

The concept of psychological capital was developed by Luthans and his colleagues on the basis of positive organizational scholarship, positive psychology, and positive organizational behavior literature (Cameron et al., 2009; Seligman and Csikszentmihalyi, 2000; Wright, 2003). It captures psychological capacities of individuals that are measurable, developable, and performance oriented (Luthans and Youssef, 2004). They have identified four resources that form the PsyCap construct including self-efficacy, hope, optimism and resilience. In that, self-efficacy refers to the belief in oneself about accomplishing a particular task of achieving a particular goal (Stajkovic and Luthans, 1998), hope refers to 'willpower' which is one's determination to achieve a goal and 'waypower' which is one's ability to keep alternate paths ready to overcome obstacles in the path of achieving goals (Snyder, 2002), optimism refers to the extent to which the individuals are persistent and pervasive (Carver and Scheier, 2002), and resilience refers to individuals' ability to manipulate their surroundings successfully to guard against adversities (Rutter, 1987) which was later-on modified as an ability to 'bounce-back' from adverse conditions (Luthans, 2002).

A large body of literature has recently examined the relationships among PsyCap, employee attitudes, and performance (Anglin et al., 2018; Carmona-Halty et al., 2018; Heled et al., 2016; Luthans and Youssef-Morgan, 2017; Malik and Dhar, 2017; Newman et al., 2018; Ngoma and Dithan Ntale, 2016; Nielsen et al., 2017; Nolzen, 2018; Pitichat et al, 2018; Pu et al., 2017; Selvaraj and Bhat, 2018; Thyrian et al., 2017; Xu et al., 2017). PsyCap comprises of the components that have been identified as precursors to employee attitudes and behaviors, yet research relating to the extent to which PsyCap affects both affective well-being and affective commitment is sparse. 
Newman et al. (2014) summarized the "agenda for future research" including "mediating mechanisms underlying the psychological capital/outcomes relationship" and the purpose of this study is precisely to examine the mediating role of Affective Well-Being in the relationship between PsyCap and Affective Commitment.

\section{Theoretical Framework and Hypotheses Development}

\subsection{PsyCap and Affective Commitment}

Affective commitment refers to an alignment felt by the employees between their (1) personal value systems and desires and (2) organization (Mellor et al., 2001). More specifically, it is the extent to which employees are emotionally attached to and involved in their organization (Çetin, 2011). The relationship between PsyCap and affective commitment can be better understood with the help of conservation of resource theory. According to this theory, individuals want to protect, replenish and invest in resources that are valuable to them (Hobfoll, 1989). Thus, if employees are psychologically capable, which means high in the four resources including hope, self-efficacy, resilience, and optimism, they would be emotionally attached with the organization as their organization is providing them necessary support for maintaining, replenishing, and investing their personal resources.

A growing body of research to date indicates that PsyCap has been found to have a positive effect on various job outcomes such as organizational commitment (Avey et al., 2011; Larson and Luthans, 2006; McMurray et al., 2010). More recently, Wu and Chen (2018) linked the collective PsyCap with organizational commitment and Idris and Manganaro (2017) tested the relationships 
between PsyCap, job satisfaction, and organizational commitment. Karatepe and Karadas (2015) examined the joint impacts of self-efficacy, hope, optimism and resilience as the indicators of PsyCap on satisfaction outcomes. Liao et al. (2017) found that PsyCap enhances job satisfaction which, in turn, has been correlated with organizational commitment (Mathieu and Zajac, 1990; Pratt, 1998). Scholars have also found PsyCap to be strongly correlated with affective commitment (Miao and Bozionelos, 2017).

H1: Self-efficacy, hope, optimism and resilience (i.e., PsyCap) have a positive influence on affective commitment.

\subsection{PsyCap and Affective Well-being}

Scholars in the past have conceptualized the relationship between PsyCap and well-being based on the conservation of resource (COR) theory (Hobfoll, 1989). PsyCap is a personal resource that tends to positively affect happiness. Luthans et al. (2013) have proposed that the positive core construct of PsyCap, consisting of the positive psychological resources of hope, efficacy, resiliency, and optimism can be extended into the well-being domain. Other studies have found that optimism has a positive influence on well-being (Scheier and Carver, 1992) and life satisfaction (Seligman, 2002). Since optimistic individuals have superior coping mechanism to handle adversity, they often experience greater happiness (Scheier and Carver, 1985; Park, 1998). In COR, it has been argued that efficacious individuals serve as a cognitive resource. Since such individuals are confident about what they do, they are less affected by self-doubt, setbacks, and other negative events and are likely to report greater happiness (Bandura and Locke, 2003). Another component of PsyCap, hope, has to do with persevering and re-directing paths to achieve a goal because of which individuals are not stressed as they have another path available when they 
find one path not working out for them. The lower levels of stress due to hope help them garner happiness (Kato and Snyder, 2005). Similarly those who are resilient, have the capacity to bounce back from failures because of which they take failures as a challenge, achieve their goals by overcoming hurdles, and become happy (Maddi, 1987).

Once individuals conserve positive energy, they are able to increase their personal resources that are the components of PsyCap (Malinowski and Lim, 2015). The conceptual explanation can be given using the Broaden-and-Build theory of positive emotions (Fredrickson, 2004). According to this theory, "positive emotions (e.g., joy, interest, and contentment) broaden an individual's momentary thought-action repertoire, which in turn can build that individual's enduring personal resources, resources that also served the ancestral function of promoting survival" (Fredrickson, 2000, p. 1). Using the Broaden-and-Build theory, the authors of this paper thus predict that the individuals would broaden their efficacy, hope, optimism, and resilience resources to have greater positive emotions in terms of affective well-being. Most of the research is limited to the hedonic component of well-being in relation to PsyCap. For example, Luthans et al. (2007) found a positive impact of PsyCap on job satisfaction. Similarly, Avey et al. (2010) found that PsyCap has a positive impact on workers' beliefs. However, the emotional or affective component of well-being still needs to be explored as a consequence of PsyCap.

H2: H1: Self-efficacy, hope, optimism and resilience (i.e., PsyCap) have a positive influence on affective well-being.

\subsection{Affective Well-being and Affective Commitment}

Affective commitment is an affect-based bond with the organization and may be defined as "identification with, involvement in, and emotional attachment to the organization" (Allen and 
Meyer, 1996, p. 253). Individuals, who feel that they are emotionally well taken care of by the organization, are likely to develop an emotional bond with their organization. In other words, if employees feel happy at work, they are likely to improve positive attitudes toward the organization, such as affective commitment (Fisher, 2002; Lilius et al., 2008). Therefore, affective well-being at work may predict this attitude called affective commitment (Weiss and Cropanzano, 1996).

Researchers have found that employees who have frequent experiences of positive emotions at work tend to develop an affective attachment with the workplace (Fisher, 2002; Fredrickson, 1998, 2003; Lilius et al., 2008; Rego et al., 2011; Weiss and Cropanzano, 1996). Reapplying the Fredrickson broaden-and-build model (Fredrickson, 1998, 2003), positive emotions probably lead employees to experience work as meaningful, thus assuming work as a 'mission' rather than as a 'job', which in turn makes them more affectively committed to their organizations (Gavin and Mason, 2004; Wright and Cropanzano, 2004). A recent empirical study found a positive relation between employee's affective well-being and their affective commitment (Semedo et al., 2019). Thus, the following hypothesis can be stated:

H3: Affective well-being has a positive influence on affective commitment.

\subsection{Mediating Role of Affective Well-being}

PsyCap emphasizes the potential value of employees assessing situations in more positive, opportunistic, and adaptive ways, thus increasing their well-being (Avey et al., 2010). Thus, PsyCap can promote well-being assessments. PsyCap is expected to lead to wellbeing and the cognitive mechanism takes place through PsyCap's positive evaluation of situations (Luthans et al., 2007). The affective mechanism takes place through the positive states produced by PsyCap, 
which can be important in the expansion of one's thought-action repertoires and building resources (Fredrickson, 2009). The core construct of PsyCap is fundamentally cognitive in nature; employees' PsyCap reinforces the potential value of evaluating the workplace in more positive ways, and it improves employees' well-being and, subsequently, the affective bond with their organization.

PsyCap has been positively associated with job satisfaction (Luthans et al., 2007) and wellbeing (Avey et al., 2010). More specifically, Optimism has been related with mental well-being (Scheier and Carver, 1992) and life satisfaction (Seligman, 2002). Hope is likely a resource that influences subjective well-being (Kato and Snyder, 2005). And resiliency predicts job satisfaction (Larson and Luthans, 2006) and happiness (Youssef and Luthans, 2007). In turn, affective wellbeing makes employees more affectively attached to their organizations (Semedo et al., 2019) and more committed to improving organizational performance (Wright and Cropanzano, 2004).

Therefore, it is believed that if PsyCap influences employees' affective well-being and the latter influences affective commitment, then affective well-being likely mediates the relationship between PsyCap and affective commitment.

H4: Affective well-being mediates the relationship between the four dimensions of PsyCap (selfefficacy, hope, optimism and resilience) and affective commitment.

Figure 1 presents the hypothesized structural model. 


\section{Method}

\subsection{Procedure and Sample}

To test the research hypotheses, a self-report survey was administered to Portuguese employees based on Google Docs-survey. The survey was sent via e-mail and social media to individuals working in different organizations in Portugal. Information on research goals, the confidentiality of the data collected, and respondents' anonymity was provided in the questionnaire. Several instructions explicitly stating that the questions had no right or wrong answers and that the respondents should answer the questions as honestly as possible were also included in the questionnaire. Other instructions were provided regarding how to complete the questionnaire to reduce possible errors.

The final sample included 226 employees from various organizations, of which $63.3 \%$ were females, $45.1 \%$ had between 18 and 30 years old and 30.1\% between 31 and 40 years old. Regarding level of education, $44.7 \%$ had a higher education degree and $21.2 \%$ are post-graduated. Regarding job tenure, $57.3 \%$ of the respondents had been employed in their organization from 1 to 5 years, $19 \%$ from 5 to 10 years, $6.6 \%$ from 10 to 15 years, and $16.8 \%$ more than 15 years.

\subsection{Measures}

\subsubsection{PsyCap (predictive variable)}

PsyCap was evaluated on a 24-item scale of the PsyCap Questionnaire (PCQ) used by Malik and Dhar (2017) and developed by Luthans et al. (2007), specifically for organizational context. The translation of these items into Portuguese followed the standard procedures for translations of research instruments (Brislin and Berry, 1986). The PCQ measures four dimensions: 
1) Self-efficacy (e.g., "I feel confident representing my work area in meetings with management"; $\alpha=.86$ )

2) Hope (e.g., "Right now I see myself as being pretty successful at work"; $\alpha=.79$ )

3) Resilience (e.g., "When I have a setback at work, I do not have trouble recovering from it, moving on"; $\alpha=.82$ )

4) Optimism (e.g., "I always look at the bright side of things regarding my job"; $\alpha=.80$ )

Using a 5-point Likert response scale (1 = "Strongly disagree"; $5=$ "Strongly agree"), employees were asked to indicate to what extent they agree with each statement presented.

\subsubsection{Affective commitment (criterion variable)}

The study measures affective commitment through 3 items proposed and validated by Rego et al. (2011). Sample items included: "I am proud to tell others that I am part of this organization" and "I feel like «part of the family» at my organization". Using a 5-point Likert response scale (1 = "Strongly disagree"; 5 = "Strongly agree"), employees were asked to indicate to what extent they agree with each statement presented. Cronbach's alpha was .91.

\subsubsection{Affective well-being (mediator variable)}

Affective well-being was measured using 15 items adapted from Daniels' (2000) research and later validated by Rego et al. (2010) in the Portuguese context. Participants were invited to think about their feelings (e.g., "anxious", "happy", "motivated") over the last three months in the organization, and to respond on a five-point scale ranging from never (1) to always (5). Cronbach's alpha was .76. 
Some items of the original measures unconsidered as they showed dubious positioning concerning the foreseen dimensions in this study.

\section{Data Analysis and Results}

\subsection{Data Analysis}

The data collected were analysed first checking for internal consistency by calculating Cronbach's alpha coefficients. A construct with a Cronbach's alpha value of more than 0.70 was considered reliable. Next, Pearson correlation coefficients were calculated to know whether the constructs are sufficiently associated with each other or not. Next, SEM analysis was done to test the proposed hypotheses, notably, the mediational hypothesis. We have done so, in order to model structural relationships and yielding overall fit indices, while estimating mediational effects (e.g. $\mathrm{Hu}$ and Bentler, 1999). We have also applied bootstrapping (Efron, 1992) (at $\mathrm{n}=1000$ units) as it permits a re-sample distribution by calculating "the statistic of interest in multiple re-samples of the data set, and by sampling $n$ units with replacement from the original sample of $n$ units" (Preacher, et al., 2007, p.190). We have also performed the Harman Test for assuring that the data do not account for significant amount of common method bias (Podsakoff et al., 2003). Descriptive statistics and variable correlations of all items are presented in Table 1.

\subsection{Results}

Means, standard deviations, internal consistency, and correlations among the established measures are listed in Table 1. All the main variables in the study inter-correlate positively. 
The starting analysis of our study's results and hypothesis have revealed that the four dimensions of PsyCap have indeed a positive influence on affective commitment (PsyCap SE Affective Commitment: $r=, 37$ / $p \leq .05$; PsyCap HO - Affective Commitment: $r .=, 54$ / $p \leq .05$; PsyCap RE - Affective Commitment: $r=, 41 / p \leq .05$; PsyCap OT - Affective Commitment: $r=$ $, 45 / p \leq .05)$. These results allow validation of our first hypothesis. Our results have also showed that PsyCap has a positive influence on affective well-being (PsyCap SE - well-being: $r=, 35 / p$ $\leq .05$; PsyCap HO - well-being: $r .=, 53 / p \leq .05$; PsyCap RE - well-being: $r .=, 41 / p \leq .05$; PsyCap OT - well-being: $r=, 45 / p \leq .05$ ). These results allow the validation of our second hypothesis. As for our third hypothesis, our results have showed that it is also supported (Well-being - Affective Commitment: $r .=, 56 / p \leq .05)$.

Proceeding with our analysis, Table 2 presents a summary of the fit indices for the theoretical model (Model 1), and also for the fit indices for the independence model (Model 2), and Figure 2 presents the theoretical model.

--- Table 2 ---

--- Figure 2 ---

Analysis of the goodness-of-fit of the proposed theoretical model (Model 1) showed good fit of the data $\left(\chi^{2}(335 \mathrm{df})=674,286(\mathrm{CMIN}) p \leq .05 ; \mathrm{RMSEA}=, 067\right.$; CFI=,914; TLI=,903), while the independence model (Model 2) has revealed unacceptable fit indices $\left(\chi^{2}(378 \mathrm{df})=4336,498\right.$ (CMIN) $p \leq .05$; RMSEA=,216; CFI $=, 000 ; \mathrm{TLI}=, 00)$. 
Regarding our fourth hypothesis, we have followed Kenny and Judd's (1984) procedure, commonly recommended for estimating mediation effects using structural equation models. According to the procedure, for total mediation effects, the total effect and the indirect effect (via mediator) should be significant, and the direct effect should be non-significant. For partial mediation effects, the direct effects should be significant, as so the indirect effects (via mediator). According to the procedure, there are evidences pointing for partial mediation effects, in line with what was foreseen in our study hypothesis. Table 3 evidences the standardized total, direct and indirect effects verified on our theoretical model.

--- Table 3 ---

It is possible to verify that the path leading from Psycap - Hope to Affective Commitment shows partial mediation effect (path Psy_HO - Affec. Commitment (Total effect=,900/ $p \leq .05$; Indirect effect=,362/ $p \leq .05$; Direct effect $=, 438 / p \leq .05$.). The remaining paths tests have revealed to be non-significant.

\section{Discussion}

\subsection{Main findings}

According to conservation of resource theory, people having more resources are likely to gain resilient towards stress, burnout, and other negative outcomes. Further, Fredrickson's (2004) Broaden and Build theory also states that individuals high in PsyCap use broader thought-action repertoires and increase the potential to make better decisions. 
The results of this research show that PsyCap promotes affective commitment and this is consistent with other studies, which reported that employees with more PsyCap are more likely to be affectively committed (Miao and Bozionelos, 2017) or report better adjustment in terms of organizational commitment in general (Avey et al., 2011; McMurray et al., 2010; Wu and Chen, 2018). However, the current findings reveal that only hope influence affective commitment via well-being in a partial mediation effect. This may indicate that, when employees are efficacious, i.e., believe in oneself about accomplishing a particular task of achieving a particular goal (Stajkovic and Luthans, 1998), resilient, i.e., when employees manipulate their surroundings successfully to guard against adversities (Rutter, 1987), and optimistic, i.e., they are persistent and pervasive (Carver and Scheier, 2002), their affective bond is not comparatively greater. In turn, when employees have the ability to keep alternate paths ready to overcome obstacles in the path of achieving goals (Snyder, 2002), i.e., hopeful, they develop more affective commitment.

The current study's results indicate that PsyCap has a positive influence on employees' affective well-being. This is, for instance, consistent with prior research on hope that have demonstrated a link between hope and subjective well-being (Kato and Snyder, 2005). For example, lower levels of stress due to hope help employees garner happiness (Kato and Snyder, 2005). The possible reason could be that employees high on PsyCap have more resources to improve their well-being.

The present findings also reveal that affective well-being was found to be impacting affective commitment significantly which is also in line with past researches that have found that employees who have frequent experiences of positive emotions at work tend to develop an affective 
attachment with the workplace (Lilius et al., 2008; Rego et al., 2011; Semedo et al., 2019). When employees feel happy at work, is probable that they develop positive attitudes toward the organization namely better affective organizational commitment (Lilius et al., 2008). Gavin and Mason (2004) suggested that happiness at work may lead employees to experience work as meaningful, thus assuming work as a mission rather than as a "job", which in turn makes them more affectively attached to their organizations.

Finally, the results demonstrate that affective well-being partially mediates the relationship between hope and affective commitment. Therefore, hopeful employees develop more affective well-being which, in turn, promotes their attachment with the organization.

Based on the COR theory, this study proposed that PsyCap promotes affective commitment through affective well-being. Even though prior research suggests that PsyCap does have a positive impact on employee's attitudes such as their affective commitment (Akhter, Ghayas, and Adil, 2012; Rego et al., 2012), research on how this relationship occurs is scarce. This study fills this gap by arguing and examining that the PsyCap and affective commitment relationship is mediated by affective well-being. The present study has also a significant contribution to the positive psychology field by testing a model of the relationships among PsyCap, employee affective wellbeing, and affective commitment, which have not yet examined within the organizational behavior literature. Thus, the current study adds to the existing theory and research on these topics.

\subsection{Managerial Implications}

The findings of the present study suggest that organizations interested in developing their employees' well-being and affective commitment would be well-advised to target employee 
PsyCap. PsyCap has been supported as a state-like resource that is open to development through brief human resource development interventions, with significant impact on performance (Luthans et al., 2008a, b, 2010). Previous research has shown that interventions can develop PsyCap (e.g., Luthans et al., 2006; Luthans et al., 2008). According to several scholars (Luthans et al., 2008c; Luthans et al., 2010), PsyCap can be developed through relatively short (two hours or so) onlinebased or face-to-face intervention training. Such training demonstrates to be useful because it increases employees' psychological capacities by 1.5 to 3 per cent (Youssef and Luthans, 2007). Therefore, organizations should develop interventions and other training methods to develop and strengthen the employees' PsyCap. According to Badran and Youssef-Morgan (2015), managers need to pay special attention to training, organizational development, job redesign, participation of employees in both goal setting and action plans, and creating an organizational culture that is more conducive to enhancing PsyCap. Moreover, rigorous selection process should be utilised to hire those candidates who are high on self-efficacy, hope, optimism and resilience. Karatepe and Karadas (2015) suggested that managers can use the PsyCap questionnaire developed by Luthans et al. (2007a) during and after the selection process. The significant relationship with affective well-being and affective commitment supported in this study, further highlights the importance of developing employees' PsyCap.

\subsection{Limitations and Directions for Future Research}

The present study has some limitations that indicate further research is needed to understand better the effects of PsyCap on employees' outcomes. One limitation is convenience sampling and although this study had a large sample size, it did not involve any probabilistic sampling which restrict the results' generalizability. In addition, the correlational and cross- 
sectional research design does not allow firm conclusions to be drawn about the causal nexus between the study's variables. Future research needs to examine possible causal relationships using longitudinal studies. Finally, the present study involves the single-source nature of our data that promotes potential inflated relationships. However, given that PsyCap, affective well-being and affective commitment are subjective in nature, they are arguably best evaluated by self-report. Thus, rather than attempting multisource ratings, future studies may be longitudinal research designs over several time points. Furthermore, Spector (2006) has provided empirical evidence suggesting common method variance does not significantly inflate correlations. Moreover, the Harman's single factor test was administered for assuring that the data does not account for significant amount of common method bias.

\section{References}

Akhter, S., Ghayas, S., and Adil, A. (2012), "Self-efficacy and optimism as predictors of organizational commitment among bank employees", International Journal of Research Studies in Psychology, Vol. 2 No. 2, pp. 33-42.

Allen, N.J., and Meyer, J.P. (1996), "Affective, continuance, and normative commitment to the organization: An examination of construct validity", Journal of vocational behavior, Vol. 49 No. 3, pp. 252-276.

Anglin, A.H., Short, J.C., Drover, W., Stevenson, R.M., McKenny, A.F., and Allison, T.H. (2018), "The power of positivity? The influence of positive psychological capital language on crowdfunding performance", Journal of Business Venturing, Vol. 33 No. 4, pp. 470-492.

Avey, J.B., Luthans, F., Smith, R.M., and Palmer, N.F. (2010), "Impact of positive psychological capital on employee well-being over time", Journal of Occupational Health Psychology, Vol. 15 
No. 1, pp. 17-28.

Avey, J.B., Reichard, R.J., Luthans, F., and Mhatre, K.H. (2011), "Meta-analysis of the impact of positive psychological capital on employee attitudes, behaviors, and performance", Human Resource Development Quarterly, Vol. 22 No. 2, pp. 127-152.

Badran, A.M., and Youssef-Morgan, C.M. (2015), "Psychological capital and job satisfaction in Egypt", Journal of Managerial Psychology, Vol. 30 No. 3, pp. 354-370.

Bandura, A., and Locke, E. (2003), "Negative self-efficacy and goal effects revisited", Journal of Applied Psychology, Vol. 88, pp. 87-99.

Baron, R.M. and Kenny, D.A. (1986), "The moderator-mediator variable distinction in social psychological research: Conceptual, strategic, and statistical considerations", Journal of Personality and Social Psychology, Vol. 51, pp. 1173-1182.

Brislin, R.W., and Berry, J.W. (1986), "The wording and translation of research instrument", in Lonner, W.J. (Ed.), Field methods in cross-cultural research. Sage Publications, Beverly Hills, CA, pp. 137-164.

Cameron, K.S., Dutton, J.E., and Quinn, R.E. (2009), "Introduction", in Positive Organizational Scholarship : Foundations of a New Discipline, Berrett-Koehler, San Francisco.

Carmona-Halty, M., Salanova, M., Llorens, S., and Schaufeli, W.B. (2018). How Psychological Capital Mediates Between Study-Related Positive Emotions and Academic Performance. Journal of Happiness Studies, 20(2), 605-617.

Carver, C.S., and Scheier, M.F. (2002), "Commentaries", Psychological Inquiry, Vol. 13 No. 4, pp. 276-321.

Çetin, F. (2011), "The effects of the organizational psychological capital on the attitudes of 
commitment and satisfaction: A public sample in Turkey", European Journal of Social Sciences, Vol. 21 No. 3, pp. 373-380.

Çetin, F., and Basim, N. (2011), "The Role of Resilience in the Attitudes of Job Satisfaction and Organizational Commitment", ISGUC, The Journal of Industrial Relations and Human Resources, Vol. 13 No. 3, pp. 79-94.

Culbertson, S.S., Fullagar, C.J., and Mills, M.J. (2010), "Feeling good and doing great: The relationship between psychological capital and well-being", Journal of Occupational Health Psychology, Vol. 15 No. 4, pp. 421-433.

Daniels, K. (2000), "Measures of Five Aspects of Affective Well-Being at Work", Human Relations, Vol. 53, pp. 275-294.

Diener, E., Larsen, R.J., Levine, S., and Emmons, R.A. (1985), "Intensity and frequency: Dimensions underlying positive and negative affect", Journal of Personality and Social Psychology, Vol. 48 No. 5, pp. 1253-1265.

Efron, B. (1992), "Bootstrap methods: Another look at the jackknife", in Kotz, S. and Johnson, N. L. (Eds) Breakthroughs in statistics, Springer, New York, NY, pp. pp. 569-593.

Fisher, C. (2002), "Antecedents and consequences of real-time affective reactions at work", Motivation and Emotion, Vol. 26, pp. 3-30.

Fredrickson, B.L. (2000), "Cultivating positive emotions to optimize health and wellbeing", Prevention \& Treatment, Vol. 3 No. 1, p. 1a.

Fredrickson, B.L. (1998), "What good are positive emotions?", Review of General Psychology, Vol. 2, pp. 300- 319. 
Fredrickson, B.L. (2003), "Positive emotions and upward spirals in organizational settings", in Cameron, K.S., Dutton, J. and Quinn, R.E. (Eds). Positive organizational scholarship, Berrett Koehler, San Francisco, pp. 163-175.

Fredrickson, B.L. (2004), "The broaden-and-build theory of positive emotions", Philosophical Transactions of the Royal Society B: Biological Sciences, Vol. 359 No. 1449, pp. 1367-1377.

Fredrickson, B. (2009), Positivity: Top-notch reveals the 3-to-1 ratio that will change your life. Harmony, Three River Express, New York.

Gavin, J.H. and Mason, R.O. (2004), "The virtuous organization: The value of happiness in the workplace", Organizational Dynamics, Vol. 33 No. 4, pp. 379-392.

Heled, E., Somech, A., and Waters, L. (2016), "Psychological capital as a team phenomenon: Mediating the relationship between learning climate and outcomes at the individual and team levels", Journal of Positive Psychology, Vol. 11 No. 3, pp. 303-314.

Hobfoll, S.E. (1989), "Conservation of resources: A new attempt at conceptualizing stress", American Psychologist, Vol. 44 No. 3, pp. 513-524.

Hu, L., and Bentler, P. (1999), "Cutoff Criteria for fit indexes in covariance structure analysis: conventional criteria versus new alternatives", Structural Equation Modeling, Vol. 6, pp. 1-55.

Idris, A.M. and Manganaro, M. (2017), "Relationships between psychological capital, job satisfaction, and organizational commitment in the Saudi oil and petrochemical industries", Journal of Human Behavior in the Social Environment, Vol. 27 No. 4, pp. 1-19.

Karatepe, O.M., and Karadas, G. (2015), "Do psychological capital and work engagement foster 
frontline employees' satisfaction?: A study in the hotel industry", International Journal Contemporary Hospitality Management, Vol. 27 No. 6, pp. 1254-1278.

Kato, T., and Snyder, C.R. (2005), "The relationship between hope and subjective well-being: Reliability and validity of the dispositional hope scale, Japanese version", Japanese Journal of Psychology, Vol. 76, pp. 227-234.

Kenny, D.A. and Judd, C.M. (1984), "Estimating the nonlinear and interactive effects of latent variables", Psychological Bulletin, Vol. 96 No. 1, pp. 201-210.

Larson, M., and Luthans, F. (2006), "Potential added value of psychological capital in predicting work attitudes", Journal of Leadership Organizational Studies, Vol. 13, pp. 44-61.

Liao, S-S., Hu, D-C., Chung, Y-C., and Chen, L-W. (2017), "LMX and employee satisfaction: mediating effect of psychological capital", Leadership \& Organization Development Journal, Vol. 38 No. 3, pp. 433-449.

Lilius, J. M., Worline, M. C., Maitlis, S., Kanov, J., Dutton, J. E., and Frost, P. (2008), "The contours and consequences of compassion at work", Journal of Organizational Behaviour, Vol. 29, pp. 193-218.

Luthans, F. (2002), "The need for and meaning of positive organizational behavior", Journal of Organizational Behavior, Vol. 23 No. 6, pp. 695-706.

Luthans, F., Yousseff, C.M. and Avolio, B.J. (2006), Psychological Capital: Developing the Human Competitive Edge, Oxford University Press, Oxford.

Luthans, F., Youssef, C.M., and Avolio, B.J. (2007), Psychological capital: Developing the human competitive edge. Oxford University Press, New York. 
Luthans, F., and Youssef-Morgan, C.M. (2017), "Psychological Capital: An Evidence-Based Positive Approach". Annual Review of Organizational Psychology and Organizational Behavior, Vol. 4 No. 1, pp. 339-366.

Luthans, F., and youssef, C.M. (2004), "Human, Social, and Now Positive Psychological Capital Management", Organizational Dynamics, Vol. 33 No. 2, pp. 143-160.

Luthans, F., Avey, J.B., Avolio, B.J., and Peterson, S. (2010), "The development and resulting performance impact of positive psychological capital", Human Resource Development Quarterly, Vol. 21, pp. 41-67.

Luthans, F., Avey, J.B., Smith, R.C., and Li, W. (2008a), "More evidence on the value of Chinese workers' psychological capital: a potentially unlimited competitive resource?",

International Journal of Human Resource Management, Vol. 19, pp. 818-827.

Luthans, F., Norman, S.M., Avolio, B.J., and Avey, J.B. (2008b), "The mediating role of psychological capital in the supportive organizational climate-employee performance relationship", Journal of Organizational Behavior, Vol. 29, pp. 219-238.

Luthans, F., Avey, J.B., and Patera, J.L. (2008c), "Experimental analysis of a web-based training intervention to develop positive psychological capital", Academy of Management Learning \& Education, Vol. 7, pp. 209-221.

Luthans, F., Youssef, C. M., Sweetman, D. S. and Harms, P. D. (2013), "Meeting the Leadership Challenge of Employee Well-Being Through Relationship PsyCap and Health PsyCap", Journal of Leadership \& Organizational Studies, Vol. 20 No. 1, pp. 118-133.

Maddi, S.R. (1987), "Hardiness training at Illinois Bell Telephone", in Opatz, P. (Ed.), Health promotion evaluation, National Wellness Institute, Stevens Point, WI, pp. 101-115. 
Malik, N., and Dhar, R.L. (2017), "Authentic leadership and its impact on extra role behaviour of nurses: The mediating role of psychological capital and the moderating role of autonomy", Personnel Review, Vol. 46 No. 2, pp. 277-296.

Malinowski, P., and Lim, H.J. (2015), "Mindfulness at work: Positive affect, hope, and optimism mediate the relationship between dispositional mindfulness, work engagement, and wellbeing", Mindfulness, Vol. 6 No. 6, pp. 1250-1262.

Mathieu, J.E., and Zajac D.M. (1990), "A review and meta-analysis of the antecedents, correlates and consequences of organizational commitment", Psychological Bulletin, Vol. 108 No. 2, pp. 171-194.

McMurray, A.J., Pirola-Merlo, A., Sarros, J.C., and Islam, M.M. (2010), "Leadership, climate, psychological capital, commitment, and wellbeing in a non-profit organization", Leadership \& Organization Development Journal, Vol. 31 No. 5, pp. 436-457.

Mellor, S., Mathieu, J.E., Barnes-Farrell, J.L., and Rogelberg, S.G. (2001), "Employees’ Nonwork Obligations and Organizational Commitments: A New Way to Look at the Relationships", Human Resource Management, Vol. 40 No. 2, pp. 171-184.

Miao, R., and Bozionelos, N. (2017), "Linking High-Performance Work Systems to Employee Attitudes: The Moderated Mediation Model", Academy of Management Proceedings, Vol. 1 doi.org/10.5465/ambpp.2016.15372abstract

Newman, A., Ucbasaran, D., Zhu, F. E. I., and Hirst, G. (2014), "Psychological capital: A review and synthesis", Journal of Organizational Behavior, Vol. 35 No. S1, pp. S120-S138.

Newman, A., Nielsen, I., Smyth, R., Hirst, G., and Kennedy, S. (2018), "The effects of diversity climate on the work attitudes of refugee employees: The mediating role of psychological capital 
and moderating role of ethnic identity", Journal of Vocational Behavior, Vol. 105, pp. 147-158.

Ngoma, M., and Dithan Ntale, P. (2016), "Psychological capital, career identity and graduate employability in Uganda: the mediating role of social capital", International Journal of Training and Development, Vol. 20 No. 2, pp. 124-139.

Nielsen, I., Newman, A., Smyth, R., Hirst, G., and Heilemann, B. (2017), "The influence of instructor support, family support and psychological capital on the well-being of postgraduate students: a moderated mediation model", Studies in Higher Education, Vol. 42 No. 11, pp. 20992115.

Nolzen, N. (2018), "The concept of psychological capital: a comprehensive review", Management Review Quarterly, Vol. 68 No. 3, pp. 237-277.

Park, C. (1998), "Stress-related growth and thriving through coping: The roles of personality and cognitive processes", Journal of Social Issues, Vol. 54, pp. 267-277.

Pitichat, T., Reichard, R.J., Kea-Edwards, A., Middleton, E., and Norman, S.M. (2018), "Psychological Capital for Leader Development", Journal of Leadership and Organizational Studies, Vol. 25 No. 1, pp. 47-62.

Podsakoff, P., MacKenzie, S., Lee, J. and Podsakoff, N. (2003), "Common method biases in behavioral research: a critical review of the literature and recommended remedies", Journal of Applied Psychology, Vol. 88, No. 5, pp. 879-903.

Pratt, M.G. (1998), "To be or not to be? Central questions in organizational identification", in Whetten, D.A. and Godfrey, P.C. (Eds), Identity in Organizations: Developing Theory through Conversations, Sage, Thousand Oaks, CA, pp. 171-207.

Preacher, K., Rucker, D. and Hayes, A. (2007), “Addressing moderated mediation hypotheses: 
Theory, methods, and prescriptions", Multivariate Behavioral Research, Vol. 42, pp. 185-227.

Pu, J., Hou, H., Ma, R., and Sang, J. (2017), "The effect of psychological capital between workfamily conflict and job burnout in Chinese university teachers: Testing for mediation and moderation", Journal of Health Psychology, Vol. 22 No. 14, pp. 1799-1807.

Rego, A., Sousa, F., Marques, C., and Cunha, M.P. (2012). Authentic leadership promoting employees' psychological capital and creativity. Journal of Business Research, 65(3), 429-437.

Rego, A., Ribeiro, N., and Cunha, M.P. (2010), "Perceptions of organizational virtuousness and happiness as predictors of organizational citizenship behaviors", Journal of Business Ethics, Vol. 93 No. 2, pp. 215-235.

Rego, A., Ribeiro, N., Cunha, M.P. and Jesuíno, J.C. (2011), "How happiness mediates the organizational virtuousness and affective commitment relationship", Journal of Business Research, Vol. 64 No. 5, pp. 524-532.

Reynolds, A., and Lewis, D. (2018), "The Two Traits of the Best Problem-Solving Teams". Retrieved from https://hbr.org/2018/04/the-two-traits-of-the-best-problem-solving-teams

Rutter, M. (1987), "Psychosocial resilience and protective mechanisms", American Journal of Orthopsychiatry, Vol. 57 No. 3, pp. 316-331.

Scheier, M., and Carver, C. (1985), "Optimism, coping, and health: Assessment and implications of generalized outcome expectancies", Health Psychology, Vol. 4, pp. 219-247.

Seligman, M.E.P., and Csikszentmihalyi, M. (2000), "Positive psychology: An introduction", American Psychologist, Vol. 55 No. 1, pp. 5-14.

Seligman, M.E.P. (2002), Authentic happiness, Free Press, New York. 
Selvaraj, P.R., and Bhat, C.S. (2018), "Predicting the mental health of college students with psychological capital", Journal of Mental Health, Vol. 27 No. 3, pp. 279-287.

Semedo, S., Coelho, A. and Ribeiro, N. (2019), "Authentic leadership, happiness at work and affective commitment: An empirical study in Cape Verde", European Business Review, Vol. 3 No. 3.

Shahnawaz, M.G., and Jafri, M.H. (2009), "Psychological capital as predictors of organizational commitment and organizational citizenship behaviour", Journal of the Indian Academy of Applied Psychology, Vol. 35, pp. 78-84.

Simons, J.C., and Buitendach, J.H. (2013), "Psychological capital, work engagement and organisational commitment amongst call centre employees in South Africa", SA Journal of Industrial Psychology, Vol. 39 No. 2. https://doi.org/10.4102/sajip.v39i2.1071

Snyder, C.R. (2002), "Hope Theory: Rainbows in the Mind", Psychological Inquiry, Vol. 13 No. 4, pp. 249-275.

Spector, P.E. (2006), "Method variance in organizational research: truth or urban legend?", Organizational Research Methods, Vol. 9, pp. 221-32.

Stajkovic, A.D., and Luthans, F. (1998), "Self-efficacy and work-related performance: A metaanalysis", Psychological Bulletin, Vol. 124 No. 2, pp. 240-261.

Thyrian, J.R., Hertel, J., Wucherer, D., Eichler, T., Michalowsky, B., Dreier-Wolfgramm, A., ... Hoffmann, W. (2017), "Effectiveness and safety of dementia care management in primary care: A randomized clinical trial", JAMA Psychiatry, Vol. 74 No. 10, pp. 996-1004.

Weiss, H.M. and Cropanzano, R. (1996), "Affective events theory: A theoretical discussion of the structure, causes, and consequences of affective experiences at work", in Staw, B.M. and 
Cummings, L.L. (Eds.), Research in Organizational Behavior, Vol. 18. Elsevier, New York, pp. $1-74$

Wright, T.A. and Cropanzano, R. (2004), "The role of psychological well-being in job performance: A fresh look at an age-old quest", Organizational Dynamics, Vol. 33 No. 4, pp. 338 351.

Wright, T.A. (2003), "The Incubator - Positive organizational behavior: An idea whose time has truly come", Journal of Organizational Behavior, Vol. 24 No. 4, pp. 437-442.

Wu, C-M. and Chen, T-J. (2018), "Collective psychological capital: Linking shared leadership, organizational commitment, and creativity", International Journal of Hospitality Management, Vol. 74, pp. 75-84.

Youssef, M.C. and Luthans, F. (2007), "Positive Organizational Behavior in the Workplace: The Impact of Hope, Optimism, and Resilience", Journal of Management, Vol. 33 No. 5, pp. 774-800. Xu, J., Liu, Y., and Chung, B. (2017), "Leader psychological capital and employee work engagement", Leadership \& Organization Development Journal, Vol. 38 No. 7, pp. 969-985. 


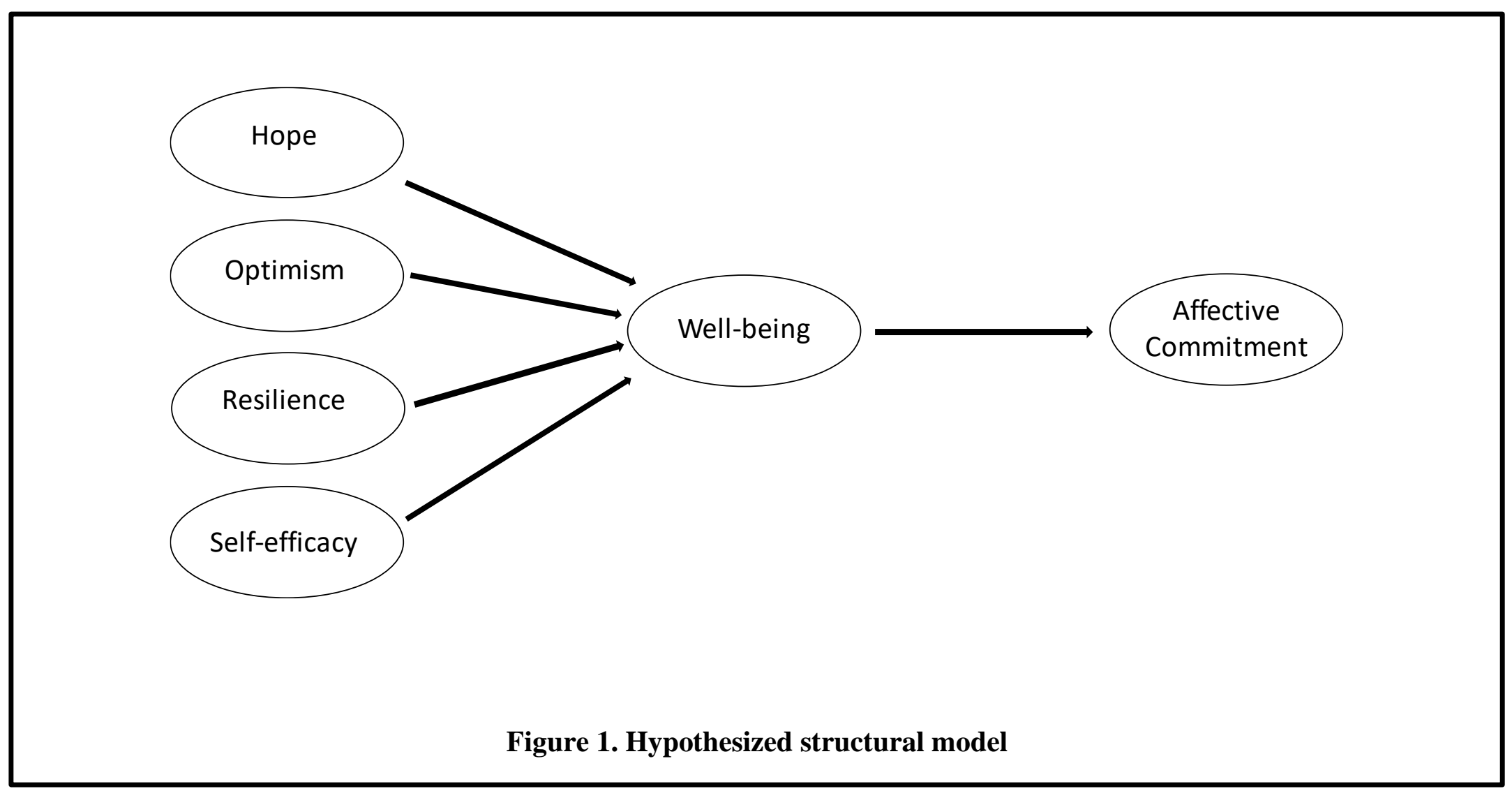


Table 1. Correlation and reliability coefficients $(N=226)$

\begin{tabular}{llllllllll}
\hline$\#$ & & Mean & SD & $\mathbf{1}$ & $\mathbf{2}$ & $\mathbf{3}$ & $\mathbf{4}$ & $\mathbf{5}$ & $\mathbf{6}$ \\
\hline 1 & PsyCap Self-efficacy & 3.62 & 0.805 & $\mathbf{0 . 8 6}$ & & & & & \\
2 & PsyCap Hope & 3.46 & 0.813 & $.630^{* *}$ & $\mathbf{0 . 7 9}$ & & & & \\
3 & PsyCap Resilience & 3.64 & 0.718 & $.721^{* *}$ & $.652^{* *}$ & $\mathbf{0 . 8 2}$ & & & \\
4 & PsyCap Optimism & 3.57 & 0.772 & $.607^{* *}$ & $.685^{* *}$ & $.802^{* *}$ & $\mathbf{0 . 8 1}$ & & \\
5 & Affective commitment & 3.33 & 1.051 & $.370^{* *}$ & $.541^{* *}$ & $.408^{* *}$ & $.447^{* *}$ & $\mathbf{0 . 9 1}$ & \\
6 & Affective well-being & 3.47 & 0.665 & $.346^{* *}$ & $.525^{* *}$ & $.414^{* *}$ & $.453^{* *}$ & $.560^{* *}$ & $\mathbf{0 . 7 6}$
\end{tabular}

Note: Boldface figures along the diagonal represent Cronbach's alpha values

$* * p<.01$

Table 2 - Goodness-of-fit indices

\begin{tabular}{ccccc}
\hline & \multicolumn{4}{c}{ Fit } \\
Models & DF & RMSEA & CFI & TLI \\
\cline { 2 - 5 } M1: Theoretical Model & 335 &, 067 &, 914 &, 903 \\
M2: Single factor model & 378 &, 216 & $, 000,000$ \\
\hline
\end{tabular}

Notes: $N=230$

Bootstrapping with sampling $=1000$ 
Figure 2 - Theoretical Model

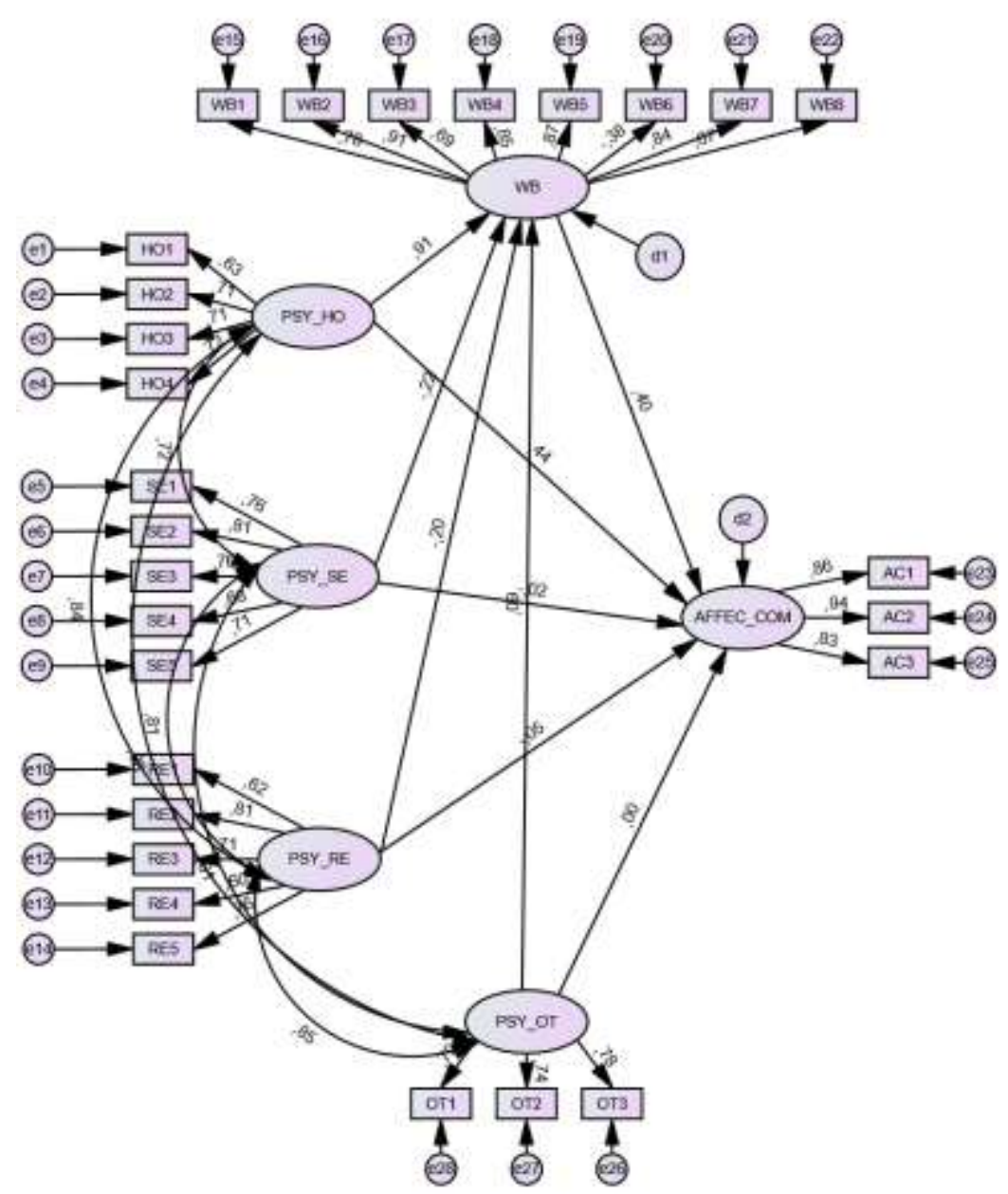


Table 3 - Theoretical Model's standardized total, indirect and direct effects

\begin{tabular}{lccc}
\hline \multicolumn{1}{c}{ Path } & $\begin{array}{c}\text { Total Effects } \\
(\text { T.E. })\end{array}$ & $\begin{array}{c}\text { Indirect Effects } \\
(\text { I.E. })\end{array}$ & $\begin{array}{c}\text { Direct Effects } \\
(\text { D.E. })\end{array}$ \\
\hline $\begin{array}{l}\text { Psy_SE - Affect. } \\
\text { Commitment }\end{array}$ &,- 114 n.s. &,- 089 n.s. &,- 025 n.s. \\
$\begin{array}{l}\text { Psy_HO - Affect. } \\
\text { Commitment }\end{array}$ &, $900^{*}$ &, $362 *$ &, $438^{*}$ \\
$\begin{array}{l}\text { Psy_RE - Affect. } \\
\text { Commitment }\end{array}$ &,- 128 n.s. &,- 081 n.s. &,- 047 n.s. \\
$\begin{array}{l}\text { Psy_OT - Affect. } \\
\text { Commitment }\end{array}$ &, 032 n.s. &, 035 n.s. &, 003 n.s. \\
\hline
\end{tabular}

$* p \leq .01 ; * * p \leq .05$ 